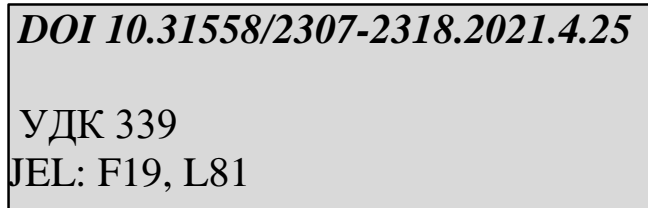

Дубель М.В.

аспірант кафедри міжнародних економічних відносин, Донецький національний університет імені Василя Стуса

ORCID: 0000-0003-2229-0419

m.dubel@donnu.edu.ua

\title{
ВПЛИВ ПАНДЕМІї COVID-19 НА ПРОЦЕС ДІДЖИТАЛІЗАЦІї СВІТОВОї ТОРГІВЛІ
}

Статтю присвячено дослідженню тенденції діджсталізації світової торгівлі в умовах пандемії COVID-19. У роботі наведено динаміку розвитку світової Інтернетторгівлі та ї частки у загальному обсязі торгівлі протягом періоду 2015-2020 років. Було виявлено наступні тенденції: щорічні темпи приросту електронної торгівлі за період 2015-2019 рр. становили приблизно 20\%, а у 2020 рочі через вплив пандеміі COVID-19 обсяг інтернет-торгівлі виріс на 27,6\% при зменшенні загального обсягу роздрібної торгівлі на 3\%. У роботі аналізується регіональний поділ електронноі комериії станом на 2020 рік. В результаті аналізу виявлено, щзо світовим лідером за обсягами продажів став Азійсько-Тихоокеанський регіон. Також, у статті наводиться аналіз темпів зростання електронної комериії. На основі аналізу висунуто гіпотезу, шьо пандемія COVID-19 стала каталізатором нової хвилі зростання темпів збільшення обсягів електронної торгівлі у «старих регіонах» - Північній Америці та Західній Європі. У дослідженні наведено провідні десять країн за обсягами продажів електронної комериіі у 2019 та 2020 роках. Виявлено одну зміну у складі лідерів замість Росії у 2020 рочі до складу потрапила Іспанія. У роботі проводиться аналіз змін обсягу та структури електронної комериії Китаю, США, Германї, Франиії, Італії, Нідерландів, Греції, Польщі та Украӥни. Внаслідок проведеного дослідження можна стверджувати, щз пандемію COVID-19 можна вважати справжнім каталізатором подальшої діджиталізації світової торгівлі.

Ключові слова: діджиталізація, пандемія COVID-19, електронна комериія, електронна торгівля, циифрова трансформація, інтернет-торгівля.

Рис. 3, Таб. 1. Літ. 20.

Постановка проблеми. Всесвітній спалах COVID-19 наприкінці 2019 року не можна розцінювати тільки як глобальну пандемію або кризу суспільної служби охорони здоров'я. Ця подія мала серйозний вплив на світову економіку і фінансові ринки. Значне скорочення доходів, зростання безробіття, перебої в роботі транспорту, сфери послуг та промисловості можна розглядати як наслідки, викликані введенням заходів з протидії поширення хвороби, які були прийняті практично в усіх країнах світу.

Водночас пандемія COVID-19 посприяла пришвидшенню темпів всесвітнього процесу діджиталізації. Найбільш суттєво діджиталізація в умовах пандемії вплинула на структуру торгівлі. Як наслідок - на тлі скорочення ринку роздрібної торгівлі відбувається стрімке зростання сектору електронної комерції, яка демонструвала 
позитивну динаміку розвитку. Всесвітня пандемія COVID-19 мала значний вплив на розвиток електронної торгівлі у світі. В деяких випадках можна було спостерігати негативний вплив пандемії на розвиток торгівлі, проте в цілому можна вважати, що всесвітня пандемія COVID-19 сприяла більш швидким темпам розвитку електронної торгівлі у порівнянні зі традиційними видами торгівлі.

Аналіз останніх досліджень та публікацій. Серед вітчизняних вчених, що присвятили свої праці дослідженню трансформацій світової торгівлі під впливом діджиталізації можна назвати С.I Туль [1], Т.Ф. Гордєєву [2], В.К. Галіцина, В.В. Дем'яненко, О.С. Камінського [3]. Однак, зважаючи на суттєві зміни, що відбулися у світовій торгівлі через пандемію COVID-19, визначення найбільш актуальних тенденцій діджиталізації торгівлі потребує подальших досліджень.

Метою дослідження $є$ аналіз впливу пандемії COVID-19 на процес діджиталізації світової торгівлі.

Виклад основного матеріалу. Розвиток міжнародної торгівлі в останні десятиліття супроводжувався, з одного боку, істотним підвищенням ролі міжнародного обміну як значимого інструменту забезпечення економічного зростання суб'єктів світового господарства. 3 іншого ж боку, під впливом науково-технічного прогресу (НТП), дія якого триває в даний час в контексті діджиталізації та цифрових трансформацій, що спостерігаються в світовій економіці, міжнародна торгівля вийшла на принципово новий етап свого розвитку, і окремим іiі сегментом, що інтенсивно розвивається, став міжнародний обмін товарами та послугами за допомогою цифрових технологій.

Цифрова трансформація сприяла істотному зменшенню витрат на участь в міжнародній торгівлі, полегшила координацію глобальних ланцюжків створення вартості (ГЛСВ), стимулювала транскордонну дифузію технологій та інновацій, зв'язала велику кількість споживачів і виробників на глобальному рівні.

Електронна комерція $є$ частиною процесу цифрової трансформації економіки. Відповідно до Декларації про глобальну електронну комерцію на Міністерській конференції СОТ у травні 1998 р., надана характеристика електронної торгівлі (еcommerce) як «виробництва, розподілу, маркетингу, продажу або постачання товарів і послуг за допомогою електронних засобів» [4]. Розвиток електронної комерції можна вважати одним з важливіших драйверів поширення процесів цифрової трансформації, що зумовлює актуальність обраної теми. В умовах пандемії саме електронна комерція стала засобом підтримання економіки та стабільності у суспільстві.

Широкому поширенню електронної торгівлі сприяє розвиток нових технологій, які забезпечують простоту та легкість будь-яких покупок у Мережі Інтернет, постійне зростання числа сайтів інтернет-магазинів, доступних в будь-який час доби, представлення повної інформації про товар, підвищення рівня захисту прав покупця. Торгівля виду В2С (від бізнесу до споживача) без посередників у вигляді торгових мереж забезпечує більш низькі ціни на товари та дозволяє економити час і гроші покупців. Швидке зростання покупок в Інтернеті призвело до структурної зміни світової торгівлі, зміни співвідношення онлайн і традиційної (офлайн) торгівлі. Виробники продають покупцям товари безпосередньо, минаючи довгий ланцюжок 3 дистриб'юторів, оптовиків і рітейлерів.

Характерною рисою електронної комерції є постійне зростання обсягів продажів, що відображено на рисунку 1. 


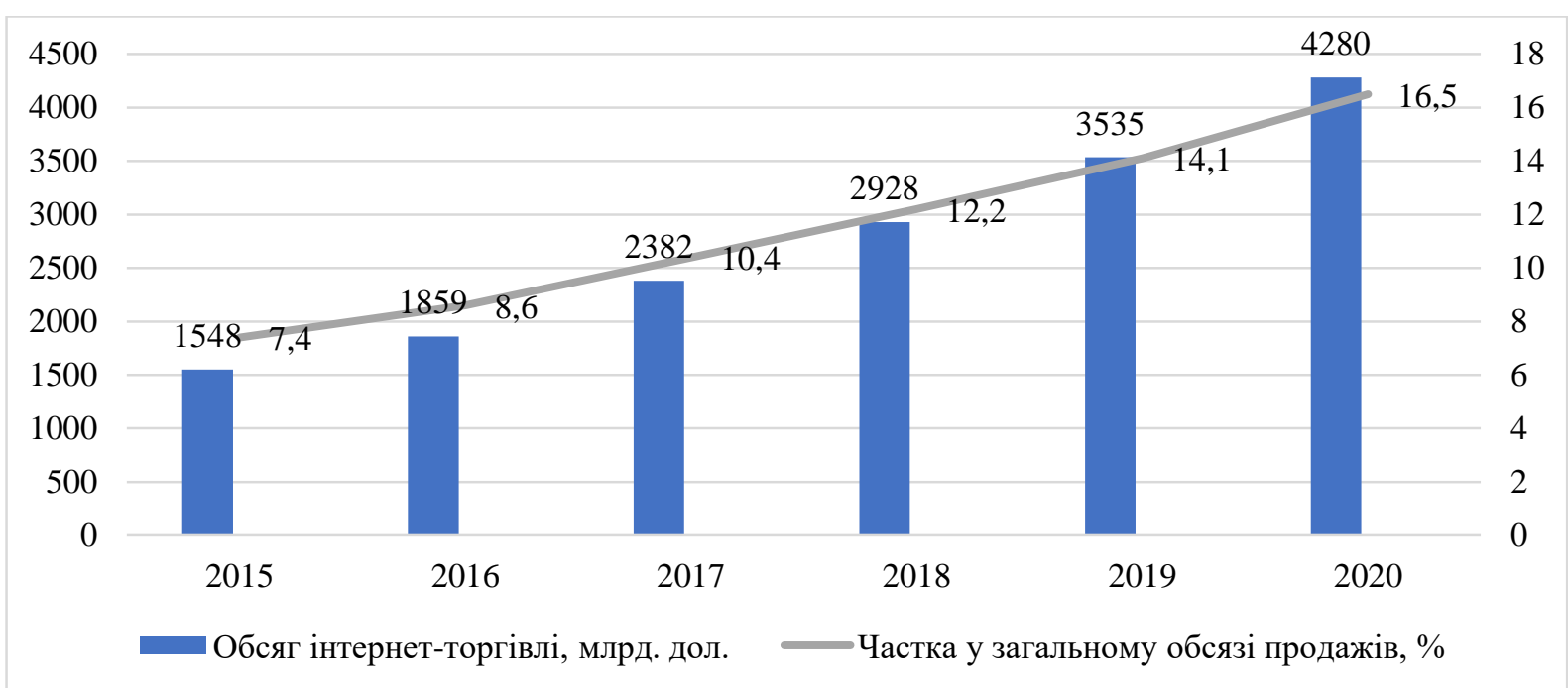

Рисунок 1 - Динаміка розвитку світової інтернет-торгівлі та ії частка у загальному обсязі торгівлі

Джерело: розроблено автором на основі [5]

Щорічні темпи приросту електронної торгівлі за період 2015-2019 рр. становили приблизно 20\%. Значний вплив на розвиток електронної комерції здійснила пандемія COVID-19. Незважаючи на те, що у зв'язку зі світовою пандемією загальний обсяг роздрібних продажів у світі знизився на 3,0\% до 23,839 трлн. доларів США, обсяг інтернет-торгівлі виріс за 2020 рік на 27,6\% і склав 4,280 трильйона доларів США.

Застосування соціального дистанціювання, карантину та інших заходів у відповідь на пандемію COVID-19 призвело до того, що споживачі стали частіше здійснювати онлайн-покупки, використовувати соціальні мережі, інтернет-телефонію та телеконференції, а також стрімінг відео і фільмів. Це призвело до різкого зростання продажів споживачам (B2C) і збільшення обсягу електронної комерції між підприємствами (В2В). Збільшення обсягів споживчих продажів особливо помітно в сегментах продажів медичних товарів, товарів для будинку, предметів першої необхідності та продуктів харчування.

Негативно на електронну торгівлю фізичними товарами і послугами вплинули ті ж фактори, які призвели до просідання попиту та пропозиції в цілому. Ці збої призвели до затримок доставки або повного скасування замовлень. Онлайн-продажі фізичних товарів і послуг через В2В і В2С канали за допомогою роздрібних і оптових дистриб'юторських послуг залежать від загального стану виробничої діяльності та доступності послуг, які, в свою чергу, були порушені заходами, прийнятими урядами для стримування поширення пандемії вірусу. По-перше, пандемічні блокування призвели до припинення виробництва у багатьох країнах, що позначилося зниженням пропозиції та зростанням безробіття. По-друге, електронна торгівля зіткнулася 3 проблемами через порушення транспортних i логістичних ланцюжків поставок, зокрема, у зв'язку з введенням нових санітарних правил, що посилили вимоги до правил наземних, морських і повітряних перевезень вантажів.

В силу наявності як позитивних, так і негативних факторів для ринку електронної комерції, що виникли у зв'язку з пандемією, актуальні статистичні дані та прогнози не піддаються однозначної інтерпретації. Додаткову складність представляє відсутність загального методологічного стандарту для розрахунку обсягів електронної торгівлі, що веде до серйозної різниці в існуючих оцінках. 
Важливим для здійснення аналізу актуального стану розвитку електронної комерції буде наведення структури обсягів продажів у залежності від регіону (рис. 2).

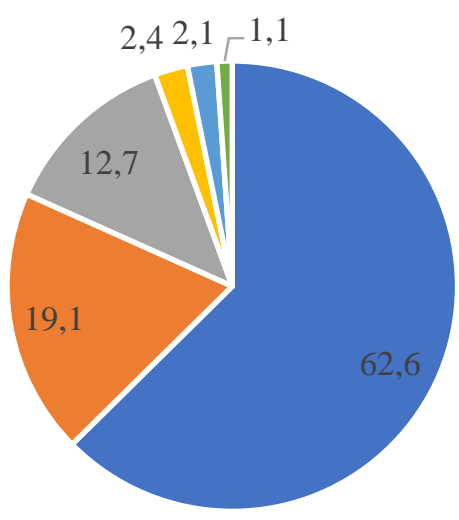

$$
\begin{array}{ll}
\text { - Азійсько-Тихоокеанський регіон } & \text { - Північна Америка } \\
\text { - Західна Європа } & \text { - Центральна та Східна Європа } \\
\text { - Латинська Америка } & \text { - Близький Схід та Африка }
\end{array}
$$

Рисунок 2 - Регіональний поділ електронної комерції у 2020 році Джерело: розроблено автором на основі [6]

Аналіз даних з регіонального поділу електронної комерції у 2020 році свідчить про те, що на Азійсько-Тихоокеанський регіон припадає більш ніж 60 відсотків світового обсягу електронної комерції. Друге та третє місце займають, відповідно, Північна Америка та Західна Європа. Інші регіони суттєвої ваги не мають.

Для кращого розуміння світових тенденцій розвитку електронної комерції слід проаналізувати особливості динаміки іi регіонального розвитку протягом останніх років.

Азійсько-Тихоокеанський регіон

Латинська Америка

Близький Схід та Африка

Центральна та Східна Європа

$$
\begin{gathered}
\text { Північна Америка } \\
\text { Західна Європа }
\end{gathered}
$$

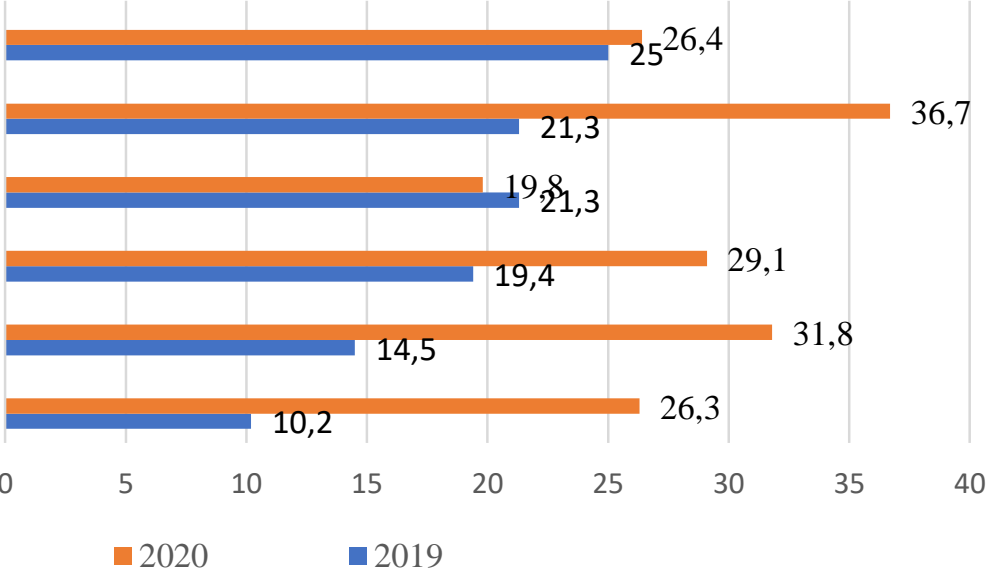

Рисунок 3 - Зростання обсягів електронної комерції у порівнянні з попереднім роком у 2019-2020 pp., \%

Джерело: розроблено автором на основі $[7,8]$ 
Слід відзначити стрімке зростання обсягів електронної комерції у 2020 році порівняно 32019 роком (більш ніж на 20 відсотків) у більшості регіонів, окрім Близького Сходу та Африки. Це пов'язано, в першу чергу, зі світовою пандемією COVID-19. Також важливою $\epsilon$ тенденція до активізації темпів розвитку електронної комерції у розвинених країн. Тобто, пандемію можна вважати каталізатором другої хвилі розвитку електронної комерції на старих ринках.

У Латинській Америці спостерігалося аномально високе зростання обсягів електронної комерції (36,7\%). У першу чергу це відбувається завдяки зростанню обсягів роздрібної електронної торгівлі в Аргентині на 79\%. Зростання обсягів електронної комерції відбувається на фоні падіння обсягів роздрібної торгівлі на 3,4\%.

Доречним буде проведення аналізу змін обсягів та темпів розвитку електронної комерції у провідних країнах світу та Україні. У таблиці 1 відображено зміни у складі та обсягах продажу електронної комерції провідних десяти країн світу.

Таблиця 1 - Топ-10 країн за обсягами продажів електронної комерції у 2019-2020 pp.

\begin{tabular}{|l|l|l|l|l|l|l|}
\hline \multicolumn{2}{|c|}{2019 рік } & \multicolumn{5}{c|}{2020 рік } \\
\hline Місце Країна & $\begin{array}{c}\text { Обсяг, млрд. } \\
\text { дол. США }\end{array}$ & Місце & \multicolumn{1}{|c|}{ Країна } & $\begin{array}{c}\text { Обсяг, млрд. } \\
\text { дол. США }\end{array}$ & $\begin{array}{c}\text { Темпиросту, } \\
\text { при }\end{array}$ \\
\hline 1 & КНР, без Гонконгу & 1934,78 & 1 & $\begin{array}{l}\text { КНР, без } \\
\text { Гонконгу }\end{array}$ & 2296,95 & 18,7 \\
\hline 2 & США & 586,92 & 2 & США & 794,5 & 35,4 \\
\hline 3 & Великобританія & 141,93 & 3 & Великобританія & 180,39 & 27,0 \\
\hline 4 & Японія & 115,40 & 4 & Японія & 141,26 & 22,4 \\
\hline 5 & Республіка Корея & 103,48 & 5 & Республіка Корея & 110,60 & 6,8 \\
\hline 6 & Німеччина & 81,85 & 6 & Німеччина & 96,86 & 18,3 \\
\hline 7 & Франція & 69,43 & 7 & Франція & 73,8 & 6,3 \\
\hline 8 & Канада & 49,80 & 8 & Індія & 55,35 & 20,2 \\
\hline 9 & Індія & 46,05 & 9 & Канада & 39,22 & $-21,2$ \\
\hline 10 & Росія & 26,92 & 10 & Іспанія & 36,4 & - \\
\hline
\end{tabular}

Аналіз даних таблиці 1 свідчить про те, що склад провідних країн за обсягами електронної комерції у 2020 році порівняно з 2019 роком змінився. Замість Росії в десятку провідних країн за обсягами електронної комерції увійшла Іспанія. Перше місце у світі зі значним відривом вже довгий час займає Китай. Слід зазначити, що дев'ять 3 десяти країн рейтингу 2020 року знаходяться у трьох регіонах - АзійськоТихоокеанському регіоні, Північній Америці та Західній Європі. Найбільші темпи приросту обсягів електронної комерції спостерігаються у США, Великобританії та Японії. Дещо втратила темпи розвитку електронної комерції Канада.

Згідно 3 даними eMarketer 44,8\% роздрібних продажів у 2020 році в Китаї припадає на електронну торгівлю, що на 10,7\% перевищує показники 2019 року. Китай наразі значно випереджає інші країни за обсягами електронної комерції. Незважаючи на те, що США, як і раніше випереджають Китай за загальним обсягом роздрібних продажів (5,506 трильйона доларів проти 5,130 трильйона доларів у 2020 році), обсяги електронної комерції Китаю у 2020 році складали на 1,6 трильйони доларів більше, ніж у США [10].

Пандемія COVID-19 вплинула на розвиток електронної комерції Китаю. Хоча Китай подолав загрозу коронавирусної інфекції набагато швидше, ніж будь-яка інша 
країна. Китай майже три квартали поспіль працював переважно в умовах нормалізованої економіки. Тим не менш, у 2020 році поведінка споживачів змінилася. Частка покупок продуктів в Інтернеті різко зросла завдяки блокуванню під час жорстких обмежень пандемії, i ця перевага може виявитися незмінною в довгостроковій перспективі. Крім того, домашні господарства залишалися нервовими протягом багатьох місяців після того, як вірус перестав бути широко поширеною небезпекою. Ця нерішучість щодо соціальної активності допомогла підтримати зростання електронної комерції.

За оцінками Digital Commerce 360, у 2020 році ринок електронної комерції у США виріс на 44\%, склавши 861,12 млрд. дол. США. Це найбільш високі темпи річного зростання е-commerce у США, принаймні протягом двох останніх десятиліть. Частка онлайн-продажів у загальному обсязі роздрібних продажів у 2020 році склала $21,3 \%$ в порівнянні з 15,8\% у 2019 році і 14,3\% у 2018 році [11].

Зростання онлайн-покупок у США, пов'язане з COVID-19, принесло у 2020 році додаткові 174,87 млрд. дол. США. Якби не сплеск онлайн-продажів в результаті пандемії, результат в розмірі 861,12 млрд. дол. США не був би досягнутий до 2022 року.

Загальний обсяг роздрібних продажів у США збільшився на 6,9\%, до 4,04 трлн. дол. США. На онлайн-продажі припав $101 \%$ всього приросту роздрібної торгівлі у 2020 році. Це означає, що продажі через всі інші канали (магазини, каталоги та колл-центри) знизилися.

За даними IMRG, онлайн-продажі у Великобританії у 2020 році зросли на $36 \%$, що $є$ найвищим показником за 13 років. Згідно з опитуванням 150 рітейлерів, споживачі витрачають стільки ж грошей, скільки і до спалаху COVID-19 [12].

Середня вартість споживчого кошика під час пандемії збільшилася в деяких секторах. У другий тиждень березня 2021 року продажі товарів для дому та саду збільшилися більш ніж на 200\%, електроніка також зберегла аналогічний рівень.

Після негативного зростання протягом усього 2020 року продажі взуття почали відновлюватися і показали позитивний результат $(27,1 \%)$ вперше 3 початку пандемії. Клієнти також купували більш дороге взуття під час пандемії, при цьому середні витрати на кошик збільшувалися під час ізоляції. Аналогічні тенденції були виявлені і в одязі: споживачі в середньому витрачали 64 фунта стерлінгів у порівнянні з 58 фунтами стерлінгів до пандемії.

Підвищився попит на доставку способом click and collect - i рітейлери швидко впровадили цю послугу. Бренди також вивчають свої поточні логістичні системи, багато хто переходить на аутсорсинг дистрибуції або бере під контроль власні фулфілментцентри. Очікується, що зростання онлайн-продажів продовжиться, і велика кількість споживачів будуть робити покупки онлайн.

У 2020 році обсяг електронної торгівлі в Німеччині виріс на 14,6\% і склав 83,3 млрд. євро, згідно з даними асоціації Bevh. Середнє зростання за попередні три роки становив 11,3\% [13]. У минулому році приблизно кожен восьмий євро з витрат домогосподарств на товари було витрачено в Інтернеті. Значне збільшення онлайнпродажів пов'язане зі спалахом коронавирусної інфекції та обмеженнями на цьому тлі.

Майже кожен третій онлайн-покупець у 2020 році був старше 60 років. У 2019 році на цю вікову групу припадало менше чверті онлайн-продажів у Німеччині.

На початок 2021 року Інтернетом користувалися 78,81 млн. громадян Німеччини, говориться у звіті We Are Social i Hootsuite [14]. Серед користувачів у віці від 16 до 64 років онлайн купівлі роблять $81,6 \%$. Майже третина населення Німеччини $(37,7 \%)$ 
робить онлайн купівлі, використовуючи мобільні пристрої Найбільший відсоток інтернет-покупців $(84,3 \%)$ знаходяться у віковій групі користувачів від 45 до 54 років.

В2С-ринок споживчих товарів в Інтернеті у 2020 році зріс на 18,6\%, до 87,6 млрд. дол. США. Один покупець в середньому витратив за рік 1404 дол. США. Онлайнвитрати в категорії «Мода і краса» склали 22,45 млрд. дол. США (зростання на 17,6\%), електроніка та фізичні медіа - 22,97 млрд. дол. США (зростання 17\%), їжа і особиста гігієна - 11,1 млрд. дол. США (зростання 28,6\%), меблі та товари для дому - 12,53 млрд. дол. США (зростання 18\%), іграшки, DIY і хобі - 18,56 млрд. дол. США (зростання 17\%).

У категорії туризму онлайн-продажі знизилися на 55\%, склавши 32,21 млрд. дол. США. Онлайн ринок таксі скоротився на 22,9\%, до 730,4 млн. дол. США. Сегмент доставки їжі збільшився на 26,6\% і досяг 2,48 млрд. дол. США.

Сектор електронної комерції у Франції виріс на 8,5\% в річному численні і досяг 112 млрд. євро у 2020 році, повідомила Федерація електронної комерції і дистанційних продажів (Fevad) [15].

У 2019 електронна комерція становила 9,8\% роздрібної торгівлі у Франції. Протягом 2020 року частка електронної комерції зросла до 13,4\% обсягів роздрібної торгівлі країн. Зростання обумовлене збільшенням продажів товарів в Інтернеті на 32\%, в той час як обсяг послуг зменшився на $10 \%$ через різке падіння кількості подорожей і розваг під час пандемії.

За останній рік в секторі з'явилося 17400 нових сайтів. На всіх сайтах з продажу продуктів і послуг було зареєстровано понад 1,84 млрд. трансакцій. Показник річного зростання трансакцій становить 5,8\%. Середній чек склав у 2020 році 61 євро, що перевищує показник попереднього року на 2 євро.

Обсяг електронної торгівлі в Нідерландах у 2020 році виріс на 7\% і склав 26,6 млрд. євро [16]. Зростання онлайн-покупок споживачами напряму пов'язане зі спалахом коронавирусної інфекції. У 2020 році голландці зробили 335 млн. онлайн-покупок, що на 27\% більше, ніж роком раніше. У 2019 один житель Нідерландів в середньому робив 19 онлайн-покупок, а у 2020 році вже 24. Крім того, кількість онлайн-покупців збільшилася на 2\%, до 13,8 млн. осіб.

У 2020 році онлайн-витрати на продукти зросли на 43\%, а кількість онлайнпокупок продуктів зросла на 41\%. У сфері послуг онлайн-продажі знизилися на $39 \%$, а число онлайн-замовлень - на $37 \%$. Високе зростання онлайн-витрат спостерігався в товарних категоріях «Будинок і побут» (зростання 83\%), «DIY / Сад» (зростання 74\%), «Спорт і відпочинок» (зростання 62\%).

За даними We Are Social i Hootsuite, станом на січень 2021 року Інтернет використовували 50,54 млн. жителів Італії [17]. Роблять онлайн-покупки 79,7\% користувачів у віці від 16 до 64 років, використовуючи мобільний телефон - 46,7\%. Найбільший відсоток інтернет-покупців спостерігається у віковій групі 24-34 роки $(81 \%)$.

У 2020 році обсяг ринку онлайн-продажів споживчих товарів в Італії зріс на $23,8 \%$, до 20,63 млрд. дол. США. У середньому один користувач за рік витратив на онлайн-шопінг 619 дол. США. У категорії «Мода і краса» онлайн-витрати склали 5,74 млрд. дол. США. (зростання 24,4\%), електроніка та фізичні медіа - 5,7 млрд. дол. США. (зростання 20,8\%), їжа і особиста гігієна - 2,91 млрд. дол. США. (зростання 38,7\%), меблі та товари для дому - 2,96 млрд. дол. США. (зростання 27,5\%), іграшки, DIY і хобі - 3,32 млрд. дол. США. (зростання 14,2\%). 
У категорії подорожей онлайн-витрати знизилися на 53,9\%, склавши 9,8 млрд. дол. США. Обсяг онлайн-ринку таксі скоротився на 42,5\%, до 158,1 млн. дол. США. Сегмент доставки їжі додав 27,5\%, склавши 858,7 млн. дол. США.

У 2020 році ринок онлайн-торгівлі Польщі став самим швидкозростаючим в Європі. За даними Statista, обсяг ринку оцінюється в 22 млрд. євро [18].

Протягом 2020 року в Польщі було запущено близько 11 тис. нових сайтів електронної комерції та інтернет-магазинів. Майже 80\% користувачів Інтернету в Польщі роблять онлайн-покупки. Ринок електронної комерції в основному складається з малих і середніх компаній.

На цьому тлі Amazon розглядає можливість запуску своєї польської версії. В даний час жителі цієї країни роблять онлайн-покупки через Amazon Germany, яка має польську версію.

На основні категорії товарів: одяг, побутову електроніку, меблі, продукти харчування та іграшки, онлайн-витрати досягли 10 млрд. євро. Зростання у порівнянні 3 2019 роком склало близько 25\%. Частка електронної торгівлі в роздрібних продажах країни значно зросла і досягла 8\%. Однак, це значно нижче, ніж в країнах Західної Європи.

Згідно з недавніми оцінками Конфедерації торгівлі та підприємництва Греції, оборот електронної комерції в цій країні у 2020 році потроївся в порівнянні 3 аналогічним періодом минулого року до 15 млрд. євро [19].

Греція відставала за обсягами та темпами зростання електронної комерції від інших країн-членів ЄС у попередні роки, але останнім часом країна здійснила значні кроки в напрямку цифрової трансформації своєї економіки. Саме тому споживачі частіше роблять покупки в електронному вигляді.

Під час першого локдауна (навесні 2020 року) в Греції зафіксовано зростання обсягу продажів інтернет-магазинів на 70-80\%. Влітку тенденція зберіглася, продажі зросли на $40 \%$ у порівнянні 32019 роком. Під час другого локдауна (почався 7 листопада 2020 р.) попит на онлайн-покупки різко виріс більш ніж на 85\%.

У Греції кожен другий споживач здійснив хоча 6 одну покупку в Інтернеті 3 моменту спалаху COVID-19. У грудні частка людей, які роблять онлайн-покупки, зросла до $61 \%$. Для порівняння: у червні 2020 року показник становив 51\%, а в грудні 2019 року $-21 \%$.

За оцінками групи компаній EVO, у 2020 році українці придбали через Інтернет товарів і послуг на суму 107 млрд. грн. Це на 41\% більше, ніж у 2019 р. В результаті зростання українського ринку е-commerce перевершило прогнози експертів майже в три рази. При цьому зросла і кількість онлайн-оплат (мінімум на 50\%). Тепер майже 9\% усіх покупок в Україні відбувається онлайн - на маркетплейсах, в онлайн-магазинах і соціальних мережах.

Висновки. В умовах пандемії та обмежень спілкування прискорився процес діджиталізації світової економіки. Саме електронна комерція стала засобом підтримання економіки та стабільності у суспільстві. Аналіз тенденцій розвитку електронної комерції під впливом пандемії COVID-19 свідчить про те, що пандемію можна вважати каталізатором другої хвилі розвитку електронної комерції на старих ринках. Рівень розвитку електронної комерції у розвинених країнах найвищій у світі, але країни, що розвиваються мають найбільші темпи зростання обсягів електронної комерції.

У регіональному аспекті головними центрами розвитку електронної комерції виступають: Азійсько-Тихоокеанський регіон, Північна Америка, Західна Свропа. 
Найбільші темпи зростання обсягів електронної комерції під впливом пандемії COVID19 (протягом 2019-2020рр.) мають наступні регіони: Латинська Америка, Північна Америка, Центральна та Східна Європа. Особливу роль у подальшому розвитку електронної комерції відіграє Китай. На частку цієї країни припадає близько половини світового обсягу електронної комерції.

Під впливом пандемії COVID-19 значно пожвавився попит на їжу та товари для особистої гігієни, товари для дому, саду, меблі, іграшки. Зросли обсяги онлайн-покупок продуктів та доставки їжі. Разом з тим, у сфері послуг онлайн-продажі знизилися переважно різке падіння кількості подорожей і розваг в умовах пандемії COVID-19.

Серед проблем, що стримують сьогодні процес діджиталізації світової економіки, можна передусім виділити проблеми, пов'язані з логістикою. Усунення цих проблем сприятиме подальшому зростанню популярності онлайн-торгівлі.

\section{СПИСОК ВИКОРИСТАНИХ ДЖЕРЕЛ}

1. Коробко, А.В., Туль, С.І. Діджиталізація міжнародної торгівлі: особливості та мегатренди. Актуальні проблеми теорії та практики міжнародних економічних відносин в умовах глобальної трансформації : матеріали наукової конференції студентів та молодих учених спещіальності 292 Міжнародні економічні відносини (м. Полтава, 2 грудня 2020 р.). Полтава : ПУЕТ, 2020. с. 42-44

2. Гордєєва Т.Ф. Сучасні тренди та чинники розвитку міжнародної електронної торгівлі." International relations, part "Economic sciences" 1 (20) 2019. с 45-47. URL: http://journals.iir.kiev.ua/index.php/ec_n/article/view/3764/3429

3. В.К. Галіцин, В.В. Дем'яненко, О.С. Камінський . Системний аналіз цифрової трансформації транскордонної торгівлі. Моделювання та інформаційні системи в економіиі〉 № 97. 2019. с 68-79. URL: https://ir.kneu.edu.ua:443/handle/2010/33919

4. Declaration on Global Electronic Commerce, Adopted on 20 May 1998 // Ministerial Conference, Secon Session, Geneva, 18 and 20 May 1998, WT/MIN (98)/DEC/2, 25 May 1998, (98-2148). URL: https://docs.wto.org/dol2fe/Pages/FE_Search/FE_S_S009DP.aspx?CatalogueIdList $=4814,34856,20308 \&$ CurrentCatalogueIdIndex $=1$

5. Retail e-commerce sales worldwide from 2014 to 2024. URL: https://www.statista.com/statistics/379046/worldwide-retail-e-commerce-sales/

6. Global Ecommerce Update 2021. URL: https://www.emarketer.com/content/globalecommerce-update-2021

7. Global Ecommerce 2019. URL: https://www.emarketer.com/content/globalecommerce-2019

8. Global Ecommerce 2020. URL https://www.emarketer.com/content/globalecommerce-2020

9. Top 10 countries ranked by retail ecommerce sales 2020-2021 illions change. URL: https://www.emarketer.com/chart/242909/top-10-countries-ranked-by-retail-ecommercesales-2020-2021-billions-change

10. In global historic first, ecommerce in China will account for more than $50 \%$ of retail sales. URL: https://www.emarketer.com/content/global-historic-first-ecommerce-chinawill-account-more-than-50-of-retail-sales

11. US ecommerce grows $44.0 \%$ in 2020. URL: https://www.digitalcommerce360.com/article/us-ecommerce-sales/

12. Strong December Caps Standout 2020 as Online Sales Growth Hits 13-Year High. URL: https://www.imrg.org/media-and-comment/press-releases/strong-december-capsstandout-2020-as-online-sales-growth-hits-13-year-high/ 
13. German E-Commerce Market Grows in Coronavirus Year 2020. URL: https://tradeandinvestmentpromotion.com/german-e-commerce-market-grows-in-coronavirusyear-2020/

14. DIGITAL 2021: GERMANY. URL: https://datareportal.com/reports/digital2021-germany

15. E-commerce in France: online sales increase by $8.5 \%$ in 2020. URL: https://www.hebergementwebs.com/ecommerce/e-commerce-in-france-online-sales-increaseby-8-5-in-2020

16. Ecommerce in the Netherlands: €26.6 billion in 2020. URL: https://ecommercenews.eu/ecommerce-in-the-netherlands-e26-6-billion-in-2020/

17. DIGITAL 2021: ITALY. URL: https://datareportal.com/reports/digital-2021italy

18. Ecommerce in Poland breaks records. URL: https://ecommercenews.eu/ecommerce-in-poland-breaks-records/

19. Survey: Greek E-Commerce Turnover Tripled to $€ 15 B$ in 2020. URL: https://www.thenationalherald.com/greece_economy/arthro/survey_greek_e_commerce turno ver_tripled to_15b_in_2020-1315575/

20. 107 млрд грн витратили українці на покупки в інтернеті. Яким був ecommerce у 2020 pоці. URL: https://evo.business/107-mlrd-grn-vitratili-ukra\%D1\%97ncina-pokupki-v-interneti-yakim-buv-ecommerce-u-2020-roci/

\section{REFERENCES}

1. Korobko, A.V., Tul, S.I. (2020) Didzhy talizaciya mizhnarodnoyi torgivli: osobly`vosti ta megatrendy`. Aktual`ni problemy` teoriyi ta prakty`ky` mizhnarodny`x ekonomichny`x vidnosy`n $v$ umovax global'noyi transformaciyi : materialy naukovoyi konferenciyi studentiv ta molody’x ucheny`x special’nosti 292 Mizhnarodni ekonomichni vidnosy`ny` (m. Poltava, 2 grudnya 2020 r.). Poltava : PUET c. 42-44

2. Gordyeyeva T.F. (2019) Suchasni trendy` ta chy`nny`ky` rozvy`tku mizhnarodnoyi elektronnoyi torgivli." International relations, part "Economic sciences" 1 (20) 2019. c 4547. URL: http://journals.iir.kiev.ua/index.php/ec_n/article/view/3764/3429

3. V.K. Galicy`n, V.V. Dem'yanenko, O.Ye. Kamins`ky`j (2019). Sy`stemny`j analiz cy`frovoyi transformaciyi transkordonnoyi torgivli. Modelyuvannya ta informacijni sy`stemy` v ekonomici (97). c 68-79. URL: https://ir.kneu.edu.ua:443/handle/2010/33919

4. Declaration on Global Electronic Commerce, Adopted on 20 May 1998 // Ministerial Conference, Secon Session, Geneva, 18 and 20 May 1998, WT/MIN (98)/DEC/2, 25 May 1998, (98-2148). URL: https://docs.wto.org/dol2fe/Pages/FE_Search/FE_S_S009DP.aspx?CatalogueIdList $=4814,34856,20308 \&$ CurrentCatalogueIdIndex $=1$

5. Retail e-commerce sales worldwide from 2014 to 2024. URL: https://www.statista.com/statistics/379046/worldwide-retail-e-commerce-sales/

6. Global Ecommerce Update 2021. URL: https://www.emarketer.com/content/globalecommerce-update-2021

7. Global Ecommerce 2019. URL: https://www.emarketer.com/content/globalecommerce-2019

8. Global Ecommerce 2020. URL https://www.emarketer.com/content/globalecommerce-2020

9. Top 10 countries ranked by retail ecommerce sales 2020-2021 illions change. URL: https://www.emarketer.com/chart/242909/top-10-countries-ranked-by-retail-ecommercesales-2020-2021-billions-change 
10. In global historic first, ecommerce in China will account for more than $50 \%$ of retail sales. URL: https://www.emarketer.com/content/global-historic-first-ecommerce-chinawill-account-more-than-50-of-retail-sales
11. US ecommerce
grows
$44.0 \%$
in
2020.
URL:

https://www.digitalcommerce360.com/article/us-ecommerce-sales/

12. Strong December Caps Standout 2020 as Online Sales Growth Hits 13-Year High. URL: $\quad$ https://www.imrg.org/media-and-comment/press-releases/strong-december-capsstandout-2020-as-online-sales-growth-hits-13-year-high/

13. German E-Commerce Market Grows in Coronavirus Year 2020. URL: https://tradeandinvestmentpromotion.com/german-e-commerce-market-grows-in-coronavirusyear-2020/

14. DIGITAL 2021: GERMANY. URL: https://datareportal.com/reports/digital-2021germany

15. E-commerce in France: online sales increase by $8.5 \%$ in 2020 . URL: https://www.hebergementwebs.com/ecommerce/e-commerce-in-france-online-sales-increaseby-8-5-in-2020

16. Ecommerce in the Netherlands: €26.6 billion in 2020. URL: https://ecommercenews.eu/ecommerce-in-the-netherlands-e26-6-billion-in-2020/

17. DIGITAL 2021: ITALY. URL: https://datareportal.com/reports/digital-2021-italy

18. Ecommerce in Poland breaks records. URL: https://ecommercenews.eu/ecommerce-in-poland-breaks-records/

19. Survey: Greek E-Commerce Turnover Tripled to $€ 15 B$ in 2020. URL: https://www.thenationalherald.com/greece_economy/arthro/survey_greek_e_commerce turno ver_tripled to $15 \mathrm{~b}$ in 2020-1315575/

20. 107 mlrd grn vy`traty`ly` ukrayinci na pokupky` v interneti. Yaky`m buv ecommerce u 2020 roci. URL: https://evo.business/107-mlrd-grn-vitratili-ukra\%D1\%97ncina-pokupki-v-interneti-yakim-buv-ecommerce-u-2020-roci/

\section{Дубель М.В. \\ ВЛИЯНИЕ ПАНДЕМИИ COVID-19 НА ПРОЦЕСС ДИДЖИТАЛИЗАЦИИ МИРОВОЙ ТОРГОВЛИ}

Статья посвящена исследованию тенденции диджитализации мировой торговли в условиях пандемии COVID-19. В работе приведена динамика развития мировой Интернет-торговли и ее доля в общем объеме торговли в период 2015-2020 годов. Были выявлены следующие тенденции: ежегодные темпы прироста электронной торговли за период 2015-2019 гг. составляли примерно 20\%, а в 2020 году из-за влияния пандемии COVID-19 объем Интернет-торговли вырос на 27,6\% при уменьшении общего объема розничной торговли на $3 \%$. В работе анализируется региональное деление электронной коммерции по состоянию на 2020 год. В результате анализа выявлено, что мировым лидером по объемам продаж стал Азиатско-Тихоокеанский регион. Также, в статье приводится анализ темпов роста электронной коммерции. На основе анализа выдвинута гипотеза, что пандемия COVID-19 стала катализатором новой волны роста темпов увеличения объемов электронной торговли в «старых регионах»-Северной Америке и Западной Европе. В исследовании приведены ведущие десять стран по объемам продаж электронной коммерции в 2019 и 2020 годах. Выявлено одну смену в составе мировых лидеров - вместо России в 2020 году в состав попала Испания. В работе проводится анализ изменений объема и структуры электронной коммерции Китая, США, 
Германии, Франции, Италии, Нидерландов, Греции, Польши и Украины. Вследствие проведенного исследования можно утверждать, что пандемию COVID-19 можно считать настоящим катализатором дальнейшей диджитализации мировой торговли.

Ключевые слова: диджитализация, пандемия COVID-19, электронная коммерция, электронная торговля, цифровая трансформация, Интернет-торговля.

\section{Dubel M.}

\section{THE IMPACT OF THE COVID-19 PANDEMIC ON THE DIGITALIZATION PROCESS OF WORLD TRADE}

The article is devoted to the study of the trend of digitalization of world trade in the context of the COVID-19 pandemic. The paper presents the dynamics of global Internet trade and its share in total trade during the period 2015-2020. The following trends were identified: the annual growth rate of e-commerce for the period 2015-2019 was approximately $20 \%$, and in 2020 due to the pandemic COVID-19 the volume of e-commerce increased by $27.6 \%$ while reducing the total volume of retail trade by $3 \%$. The paper analyzes the regional division of e-commerce as of 2020. The analysis revealed that the Asia-Pacific region became the world leader in terms of sales. Also, the article provides an analysis of the growth rate of e-commerce. Based on the analysis, it is hypothesized that the COVID-19 pandemic has catalyzed a new wave of growth in e-commerce in the "old regions" - North America and Western Europe. The study shows the top ten countries in terms of e-commerce sales in 2019 and 2020. One change in the composition was revealed - instead of Russia in 2020, Spain joined the composition. The paper analyzes the changes in the volume and structure of ecommerce in China, the United States, Germany, France, Italy, the Netherlands, Greece, Poland and Ukraine. As a result of the study, it can be argued that the COVID-19 pandemic can be considered a real catalyst for further digitalization of trade.

Keywords: digitalization, COVID-19 pandemic, e-commerce, e-trade, digital transformation, Internet-trading. 